Article

\title{
A Study on the Effects to Students' STEM Academic Achievement with Chinese Parents' Participative Styles in School Education
}

\author{
Guiqing $\mathrm{An}^{1}$ \\ East China Normal \\ University \\ Yang Yang ${ }^{3}$ \\ Qingdao University
}

\author{
Jingying Wang ${ }^{2}$ \\ Qingdao University \\ $\mathrm{Xin} \mathrm{Du}^{4}$ \\ Xi'an Jiao Tong \\ University
}

\begin{abstract}
There is currently a significant body of research confirming that parental participation in school education has a positive influence on students' academic achievement. However, more research is needed concerning how different styles of parents' participation and parents' demographic characteristics influence academic achievement in STEM subjects, especially considering empirical evidence from China's social context. This research is conducted to explore the influence of family environment and parents' cognitive, emotional and behavioral participation in children' school education on students' overall STEM academic achievement. In general, in the socioeconomic environment of a family, parents' education level has the greatest impact on the academic achievement of children, and the impact of family income is relatively weak. In the three models in which parents participate in their children's school education, emotional participation has the greatest impact on children' STEM academic achievement, and can compensate for the negative effects brought about by some adverse family factors
\end{abstract}

\section{Keywords}

Academic Achievement • Parental Participation • Parents' Participative Styles • STEM

\footnotetext{
The authors gratefully acknowledge the support provided by The Peak Discipline Construction Project of Education at East China Normal University.

${ }^{1}$ Institute of Curriculum and Instruction, Faculty of Education, East China Normal University, Shanghai, 200062, P. R. China. Email: gqan@kcx.ecnu.edu.cn

${ }^{2}$ Correspondence to: Jingying Wang, Normal College \& School of Teacher Education, Qingdao University, Qingdao, 266071, P.R. China. Email: wangjingying8018@126.com

${ }^{3}$ Normal College \& School of Teacher Education, Qingdao University, Qingdao, 266071, P.R. China. Email: yyang37@buffalo.edu

${ }^{4}$ Xin Du, College of Humanities and Social Sciences, Xi'an Jiao Tong University, Xi'an, 710069, P. R. China. Email: duxin@muc.edu.cn
}

Citation: An, G., Wang, J., Yang, Y., Du, X. (2018). A Study on the Effects to Students' STEM Academic Achievement with Chinese Parents' Participative Styles in School Education. Educational Sciences: Theory \& Practice, 19(1),41-54. http://dx.doi.org/10.12738/estp.2019.1.0180 
According to research in the past few decades, parents' participation plays an important role in children's academic achievement, cognitive, social and emotional development. Compared to other family factors, such as social economic status, household size, education attainment of parents, parents' participation is the most effective factor in predicting children's academic achievement (Flouri \& Buchanan, 2004; Kellaghan, Sloane, Alvarez, \& Bloom, 1993). A number of scholars agree that parental participation is a general term to describe parenting activity that includes education belief, academic expectation, and employing ways to improve students' academic achievement (Seginer, 2006; Toren, 2013). A number of studies have shown that parents' participation has a positive influence on students' academic achievement of Science, Technology, Engineering \& Mathematics (STEM) (Christenson, Rounds, \& Gorney, 1992; Epstein, 1992; Fan \& Chen, 2001). For example, Tan \& Goldberg (2009) found that parents' school participation has more significant influence on academic achievement in individual STEM subjects. One of the most cited models for understanding parents' participation is that of Joyce L. Epstein (1990, 2001). Epstein (1990) described six "overlapping spheres of influence" or types of interactions among parents, school officials, teachers, and community members. However, based on the research literature and the actual experiences of parents, teachers and researchers, Rodriguez, Parks \& Garza (2013) identified that some domains have not been included in Epstein's overlapping influence range, i.e. parents' agency, students' agency and parental expectations/aspirations. They proposed a revision of Epstein's model that includes the dynamic aspects of interactions among parents, teachers/ schools, and students. These interactions are discussed within three broad dimensions: home environment (parents and students), parents and school/community environment, and students and school/community environment.

\section{Literature Review}

Current research concerning interaction theory in the area of parents' participation mostly uses the twodimensional framework of home-based and school-based participation (Epstein, 2001; Epstein \& Sanders, 2002). Parents' participation includes home-based and school-based participation, which are categorized into four types: family discussion, family supervision, school communication, and school participation (Ho, 1995). Hill and Tyson (2009) define parental participation from the interaction perspective and view parental participation as how parents facilitate academic success through interacting with schools and their children. Through further regression analysis, they identify three modes of interaction that affect students' examination grades: school-based participation, home-based participation, and academic socialization. Some consider this final mode of interaction-academic socialization, as a component of home-based parental participation, because it is part of the academic communication parents have with their children at home (Pomerantz, Moorman, \& Litwack, 2007).

Another influential viewpoint defines parents' participation from the perspective of resources. The multiple ways of parents' participation include the following: parents' behavioral participation, parents' emotional participation and parents' cognitivelintellectual participation. School characteristics also affect how parents' participation influences students' academic achievement. Some researchers conclude that parents' participation evolves with community context (Prater, et al., 1997; Feuerstein, 2000). Looking at existing meta-analyses, 
An, Wang, Yang, Du / A Study on the Effects to Students' STEM Academic Achievement with Chinese Parents....

Castro et al., (2015) identify the 7 categories of parents' participation: General description of parents' participation, communication with children on school issues, homework, parental expectations, reading with children, parental attendance and participation in school activities, and parental style. The greatest impact comes from parental expectation, which is consistent with other meta-analyses (Fan \& Chen, 2001; Jeynes, 2005). Family communication has the second biggest impact, and reading, overall participation, and parenting style are all very important factors. The influences of parents' participation on academic achievement of different subjects, ordered from the most to the least, are: fine arts and music, reading, math, foreign language, and science (Wei, Wu, Lv, Zhou, Han, Liu, \& Luo, 2016).

On both the global and local scale, STEM has become an essential powerhouse for economic progress and for boosting global competitiveness; an important aspect of K-12 education Improving STEM academic achievement has become the goals for research on K-12 education in countries all over the world (Wang, Jou, Lv, \& Huang, 2018). By looking at existing meta-analyses, several key features of how parents' participation influences students' STEM achievement could be found. Fan and Chen (2001) demonstrate a relationship between parents' participation and students' academic achievement on STEM. When STEM achievement is measured as aggregated test scores, the correlation is stronger than when measured separately for each subject. Jeynes (2003) finds positive and significant impact on STEM achievement across all racial groups, and the strength of the relationship is moderated by inter-racial relationship.

A number of studies show that parental expectations have the greatest impact on students' achievement in STEM subjects (Codjoe, 2007; Fan \& Chen 2001; Hill \& Tyson, 2009; Hong \& Ho, 2005; Lee \& Bowen, 2006). The studies adopted meta-analysis, quantitative and qualitative methods etc., and the results show that parental expectations are positively related to their children's higher academic achievement. Another study shows that there are differences between regions (Cooper, Chavira \& Mena, 2005). Jeynes (2005) made a meta-analysis of students in urban primary schools, and his conclusion is consistent with those of Fan and Chen (2001), that is, parental expectations have a great impact on children's STEM academic achievement; however, parental participation in school affairs and checking their children's homework have little effect on their STEM academic achievement. A common assumption is that if parents can give their children some guidance in their homework, their children's academic achievement in STEM subjects will be improved. However, studies have not found a strong link between parental coaching with homework in STEM subjects and students' academic performance (Hill \& Tyson, 2009). It is not enough just to encourage parents to help children with their homework. Instead, specialized design with specific strategies and themes should be considered for parental participation. The Teachers Involve Parents in Schoolwork (TIPS) Interactive Homework project has changed students' attitudes and improved their performance in mathematics (especially for girls and African-Americans), although the effects on science are not obvious (Van Voorhis, 2003). Parents who regularly engage in school affairs and have high educational expectations for their children positively influence their children's academic achievement (Lee \& Bowen, 2006).

The two definitions described above are not in conflict. Resource theory not only considers the dynamic resources, which are formed through the interactions between parents and schools with children, but also the fact that families provide for children's static resources in the form of education environment and conditions. If integrating Interaction Theory and Resource Theory to get a analytic framework of parents' participation, home- 
An, Wang, Yang, Du / A Study on the Effects to Students' STEM Academic Achievement with Chinese Parents....

$\overline{\text { based participation, school-based participation, and community-based participation proposed in the interaction }}$ theory capture the interactive scenario of parents participation. In resource theory, behavior, and personal/emotional and cognitionlintelligent participation showcase the characteristics of parents' participation. Therefore, using the two-dimensional framework of scenario by characteristics of parental participation, we can have the overall framework for describing how parents participate in children's school education in STEM subjects (Table 1).

Table 1

Overall Descriptive Framework for Parental Participation in School Education

\begin{tabular}{llll}
\hline & \multicolumn{1}{c}{ Behavioral participation } & Cognitive participation & \multicolumn{1}{c}{$\begin{array}{l}\text { Emotional } \\
\text { participation }\end{array}$} \\
\hline $\begin{array}{llll}\text { Home-based } \\
\text { participation }\end{array}$ & $\begin{array}{l}\text { Parent supervision and help } \\
\text { Parent-children communication }\end{array}$ & $\begin{array}{l}\text { Providing cognition } \\
\text { stimulating materials }\end{array}$ & \\
\cline { 1 - 3 } $\begin{array}{l}\text { School-based } \\
\text { participation }\end{array}$ & $\begin{array}{l}\text { Parent-school communication } \\
\text { participation in school activities }\end{array}$ & $\begin{array}{l}\text { Participating in parent- } \\
\text { school cooperation }\end{array}$ & $\begin{array}{l}\text { Education beliefs } \\
\text { and expectations }\end{array}$ \\
\cline { 1 - 2 } $\begin{array}{l}\text { Community- } \\
\text { based } \\
\text { participation }\end{array}$ & $\begin{array}{l}\text { Providing after-school private } \\
\text { tutoring opportunities or providing } \\
\text { rides, waiting }\end{array}$ & $\begin{array}{l}\text { Participating in studies } \\
\text { during private tutoring }\end{array}$ & \\
\hline
\end{tabular}

STEM cultivates 21 st century skills and good decision-making abilities in healthcare, environmental protection, energy, and national security. But in Mainland China, there are no schools with a specialization in STEM subjects or educational efforts that synthesize the STEM subjects. In many studies of the influence of parental participation in school affairs on STEM education, researchers often adopt the expectancy-value theory (Harackiewicz, Rozek, Hulleman \& Hyde, 2012), which is one of the most influential theories in motivational psychology. The theory holds that the motivation of an individual to perform various tasks is determined by his expectation of the likelihood of success of the task and the value attached to that task. The greater the likelihood of realizing the goal in the eyes of the individual, the greater the incentive the individual obtains from the goal and the greater the motivation of the individual to accomplish the task. Studies of STEM achievement based on the expectancy-value theory) show that parents also influence their children's learning motivations (e.g., Ames, 1992; Grolnick \& Ryan, 1989; Hokoda \& Fincham, 1995; Kamins \& Dweck, 1999; McInerney, 2008; Wentzel, 1998). Parents can support children's STEM learning through emphasizing the value of study (Lamborn, Brown, Mounts \& Steinberg, 1992) or their responses to their children's academic success or failure (Kamins \& Dweck, 1999). Students who are highly supported and encouraged by their parents tend to adopt more mastery objectives and fewer performance objectives, and show more persistence and put more effort in difficult learning tasks (Hokoda Fincham, 1995; Wentzel, 1998). The study also shows a positive relationship between parental participation in schooling and a number of motivational variables, including school participation, intrinsic motivation and mastery objectives (Schunk et al., 2008). It can be inferred that the influence of parental expectation on the academic achievement of children in STEM subjects is formally determined by the value that the parents give to their children, and thus the students' adherence to completing STEM subjects is the result of their parental expectation. Parents may support students' engagement by emphasizing the value of learning (Lamborn, Brown, Mounts, \& Steinberg, 1992) or via their responses to academic success or failure (Kamins \& Dweck, 1999). Students who are highly supported and encouraged by their parents tend to adopt more mastery goals and less performance goals and to demonstrate more persistence and effort during difficult 
$\overline{\text { STEM learning tasks (Hokoda \& Fincham, 1995; Wentzel, 1998). The literature also shows positive relations }}$ between parental participation in schooling and several motivational variables, including school engagement, intrinsic motivation, and mastery goals (Schunk et al., 2008).

Even from the perspective of educational equality, little has been studied about how social economic status and participation ways of Chinese parents influence the academic achievement in STEM subjects. Therefore, based on findings of the two-dimensional framework and key categories of parents' participation, this research studies the following questions:

1. Do social economic status of parents and household structure impact academic achievement of Chinese students' STEM subjects? How does each component variable influence the academics?

2. What influences do parents' participation in cognition, emotion, and behavior have on academic achievement of Chinese students' in STEM subjects?

3. How do different variables at each dimension of Chinese parents' participation influence their children's academic achievement in STEM?

\section{Method}

\section{Sample Selection and Instrument}

This research uses the sample data of parental survey from the Database of Investigation of Curriculum and Instruction in China (ICIC). The database was built and maintained by the Research Institute of Curriculum and Instruction at a key research base of Humanities and Social Sciences of the Ministry of Education in China. The database includes 4 sections: parental surveys, teacher surveys, principal surveys, and student surveys. The parental survey asks about the basic information of children at home and the participation of parents or any other family members in the academic activities of the children. This includes basic information concerning the family environment, behavior participation, emotional participation, and cognition participation. The teacher survey has five parts: basic teacher information, relationship between teachers and curriculum, teachers and students, teachers and schools, and teachers and parents. The principal survey has two parts, A and B, and it covers areas such as basic school information, leadership, management, the practice and evaluation of curriculum and instruction quality, etc. The students survey also has A and B sections that mainly examine the daily academic and life experience of students (this includes basic information concerning the students and their families, learning opportunities inside and outside of school, academic studies of Chinese and Mathematics and the students' wellbeing. This paper uses mainly the parental survey data.

\section{Procedure and Data Analysis}

From comprehensive meta-analysis, it is evident that the majority of existing research studies the relationship between academic performance and parental expectation, family-school communication, participation in school activities, family control (mostly homework), after-school private tutoring, and parenting style. Based on the parental surveys in database, parents' participation is put into the following six categories:

1) Parental expectation, which is measured by the highest educational level parents expect of communicate to 


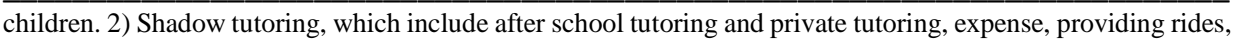
accompaniment, participation in the studying etc. 3) Family communication, which includes style, willingness, communication about academics, etc. 4) School communication such as parents contacting teachers, making suggestions, communication with teachers in terms of academic performance, behavior and development. 5) School participation, which includes school open day, parents meeting, training or conferences for parenting, volunteering, and participation in school's administrative decisions. 6) Family control, which includes tutoring and supervision of homework, reading with children, watching TV with children, regulating time for digital entertainment. The measurement of family social economic status includes father's highest educational level attained, mother's highest educational level attained, and family annual income. The survey is done in the capital city of a province of China. Mathematics, physics, biology and geography are chosen, because only students in 8th grade study all 4 subjects. Chemistry is not included since the survey didn't include students in the 9th grade. Based on area size and number of schools, the sampling is made so that the areas are comparable in the proportions of schools of excellent, average and poor qualities.

Table 2

Categorization of Related Measurements in Parental Survey

\begin{tabular}{|c|c|c|c|}
\hline & $\begin{array}{c}\text { Behavior } \\
\text { Participation (7) } \\
\end{array}$ & $\begin{array}{c}\text { Cognition } \\
\text { Participation (9) } \\
\end{array}$ & $\begin{array}{c}\text { Emotional } \\
\text { Participation (7) } \\
\end{array}$ \\
\hline $\begin{array}{l}\text { Home-based } \\
\text { participation }\end{array}$ & $\begin{array}{l}\text { Parent supervision and } \\
\text { guidance } \\
\text { Frequent book } \\
\text { purchase }\end{array}$ & $\begin{array}{l}\text { Free individualistic } \\
\text { development } \\
\text { Heart-to-heart education } \\
\text { Reward-and-punishment }\end{array}$ & $\begin{array}{l}\text { Academic expectation } \\
\text { Conflict of opinions } \\
\text { Frequent } \\
\text { communication with } \\
\text { children }\end{array}$ \\
\hline $\begin{array}{l}\text { School-based } \\
\text { participation }\end{array}$ & $\begin{array}{l}\text { Participating in school } \\
\text { activities } \\
\text { Communicating with } \\
\text { teachers } \\
\text { Making suggestions to } \\
\text { school }\end{array}$ & $\begin{array}{l}\text { Emphasis on character } \\
\text { building } \\
\text { Emphasis on grades } \\
\text { Emphasis on test ranks } \\
\text { Point out test mistakes } \\
\text { Emphasis on academic } \\
\text { progress }\end{array}$ & $\begin{array}{l}\text { Satisfaction with grades } \\
\text { Satisfaction with school } \\
\text { Expectation for school } \\
\text { to improve }\end{array}$ \\
\hline $\begin{array}{l}\text { Community- } \\
\text { based } \\
\text { participation }\end{array}$ & $\begin{array}{l}\text { Frequent participation } \\
\text { in non-formal studies } \\
\text { Whether to participate } \\
\text { in after-school tutoring }\end{array}$ & $\begin{array}{l}\text { Whether to study the content } \\
\text { and requirements with during } \\
\text { private tutoring }\end{array}$ & $\begin{array}{l}\text { Understanding of } \\
\text { children's social life } \\
\text { with peers }\end{array}$ \\
\hline
\end{tabular}

This includes basic information concerning the family socioeconomic environment, behavioral participation, cognitive participation and emotional participation. The analysis focuses on the impact on the overall performance in STEM subjects as affected by certain characteristics of parents' participation and family socioeconomic environment. According to the overall descriptive framework for parents' participation in education in Table 1, questions regarding parents' participation in the parental survey were put into horizontal factors of behavioral, cognitive, emotional participation, and vertical factors of home-based, school-based and community-based participation. Behavior participation has 6 dimensions, cognition has 9 dimensions, and emotion has 7 dimensions, with the specifics shown in Table 2. Questionnaire Items selected from parental survey of ICIC is more specific to distinguish parents' participative style, which is the rationale of using single item, rather than dimensions to run the logistic regression in the data analysis part. The dependent variable is the grades in STEM subjects that students in both the $7^{\text {th }}$ grade and $8^{\text {th }}$ grade have in the database. The STEM 
subjects referenced in this study are Mathematics, Physics, Biology and Geography. The 4 independent variables are family socioeconomic environment, parents' behavioral participation, cognitive participation and emotional participation (Table 2). The sample size is 12,724 . Of these, 6,540 of which are in the $7^{\text {th }}$ grade and 6,184 in the $8^{\text {th }}$ grade. Variables for family socioeconomic environment include parents' level of education completed, family annual income, family living style (whether a family lives with old people), and family structure (single parent or not).

\section{Results}

This research uses nested logistic regression, regressing STEM subject grades against participation mechanisms in nested regression analysis. M1 is variables of family socioeconomic environment. M2, M3 and M4 are behavioral, cognitive and emotional participation of parents respectively. The row with missing coefficients or standard errors represents the reference group. The nested logistic regression represents the statistical model with controlling effect. In the four models, model 1 explains the impact on STEM academic performance of family environment; model 2 explains additionally the impact of parental participation in behavior on STEM academic achievement; model 3 explains the impact attributable to cognitive participation of parents; and model 4 explains the impact attributable to emotional participation of parents. The descriptive statistical results of variables are shown in table 3, and the results of regression models are shown in table 4.

When each of the three ways of parents' participation in children's education is included in the model, the explanatory power for academic performance in STEM subjects increases gradually. Among variables of family socioeconomic environment in Model 1, family structure, i.e. whether it is a single-parent family has the largest impact on children's STEM academic achievement, and also parents' education level has a large impact. There's significant influence of family living style, i.e. if grandparents are living with the family. In Table 4, Parents' education level has a significant impact on children's STEM academic achievement in all four models; family income only affects the cognitive participation model; family living style has effect in all models except the behavioral participation model and family structure has influence on all models, and parental behavior and emotional participation can weaken the influence of family structure to a certain extent. Parents supervision has a significant impact on children's STEM academic achievement in behavioral and cognitive model, and parents' emotional participation can weaken the influence of parents supervision to a certain extent; Participating in after-school tutoring has a negative significant impact in the last three models; Relationship with teachers and Making suggestions to school only have a negative impact in behavioral participation; Emphasis on test ranks, character building, Free individual development and Heart-to-heart education have a significant impact in both cognitive and emotional models; Pointing out reasons for errors in exams, Emphasis on grades and academic progress only have a positive or negative impact in cognitive model, while emotional participation can weaken these influence. Studying with children during tutoring may have significant negative impact in both cognitive and emotional models. Expectations for degrees to be obtained, Conflict in opinions, Satisfaction with grades and Frequent communication with children have a significant impact in emotional model, while only Social life with peers has the negative impact. 
Table 3

Descriptive Statistics of the Variables*

\begin{tabular}{|c|c|c|c|c|c|}
\hline Variable & Obs & Mean & Std.Dev. & Min & Max \\
\hline Test scores of STEM subjects & 11421 & 71.45 & 17.58 & 49 & 500 \\
\hline \multicolumn{6}{|l|}{$M_{1}$ : Family Socioeconomic Environment (4) } \\
\hline Parents' highest education level achieved & 12202 & 2.57 & 3.29 & 0 & 6 \\
\hline Family annual income & 12196 & 3.21 & 3.52 & 0 & 8 \\
\hline Family living style (whether grandparents live with) & 12183 & 1.62 & 2.34 & 0 & 7 \\
\hline Family structure (whether single-parent family) & 12369 & 0.74 & 0.23 & 0 & 2 \\
\hline \multicolumn{6}{|l|}{$\mathbf{M}_{2}$ : Behavioral Participation of Parents (7) } \\
\hline Parent supervision and guidance & 11710 & 25.56 & 10.52 & 0 & 40 \\
\hline Frequent book purchase & 12437 & 2.36 & 1.82 & 0 & 3 \\
\hline Participating in school activities & 12100 & 2.05 & 2.38 & 0 & 16 \\
\hline Frequent participation in informal studies & 12424 & 1.63 & 2.78 & 0 & 3 \\
\hline Communicating with teachers & 12210 & 0.53 & 0.50 & 0 & 1 \\
\hline Making suggestions to schools & 12121 & 0.17 & 0.38 & 0 & 1 \\
\hline Participating in after-school tutoring & 12351 & 0.46 & 0.50 & 0 & 1 \\
\hline \multicolumn{6}{|l|}{$M_{3}$ : Cognitive Participation of Parents (9) } \\
\hline Emphasis on test ranks & 11043 & 0.56 & 0.24 & 0 & 1 \\
\hline Pointing out reasons for test errors & 11043 & 0.32 & 0.47 & 0 & 1 \\
\hline Emphasis on academic progress & 11043 & 0.49 & 0.50 & 0 & 1 \\
\hline Heart-to-heart style education & 12369 & 0.89 & 0.31 & 0 & 1 \\
\hline Reward-punishment style education & 12369 & 0.55 & 0.23 & 0 & 1 \\
\hline Studying with children during after-school tutoring & 12351 & 0.49 & 0.47 & 0 & 1 \\
\hline Free individualistic development & 11616 & 0.48 & 0.50 & 0 & 1 \\
\hline Emphasis on character building & 11616 & 0.11 & 0.31 & 0 & 1 \\
\hline Emphasis on grades & 11043 & 0.35 & 0.48 & 0 & 1 \\
\hline \multicolumn{6}{|l|}{$\mathbf{M}_{4}:$ Emotional Participation of Parents (7) } \\
\hline Expectations for degrees to be obtained by children & 12276 & 3.28 & 2.12 & 0 & 4 \\
\hline Conflict in opinions & 12319 & 0.63 & 0.48 & 0 & 1 \\
\hline Satisfaction with grades & 12423 & 0.31 & 0.46 & 0 & 1 \\
\hline Satisfaction with school & 12366 & 0.89 & 0.31 & 0 & 1 \\
\hline Expectations for school to improve & 12561 & 2.07 & 0.98 & 0 & 4 \\
\hline Frequent communication with children & 12423 & 0.88 & 2.02 & 0 & 3 \\
\hline Understanding of children's social life with peers & 10409 & 6.37 & 4.48 & 0 & 12 \\
\hline
\end{tabular}

Note. Obs: Observations, Mean: Average value, Std.Dev.:Standard Deviation, Min:Minimum, Max:Maximum.

Overall, family environment explains about $6.9 \%$ of the variation of students' STEM achievement. In model 2, with variables of parental participation in behavior included, the influence of family living style is decreased, no longer having significant impact on STEM achievement, while parent supervision and guidance has the largest impact, and the second is whether parents make suggestions to school. However, the participation of parents in after-school tutoring and contacting teachers has negative relations with STEM academic achievement. Model 2 explains $8.8 \%$ of the variations in STEM academic achievement. In model 3 where parents' cognitive participation is added, family income starts to have an impact, but the impact of household structure is decreased, and that of communication with teachers and making suggestions to school ceases to be significant. Variables measuring parents' cognitive participation, such as emphasis on exam ranks, emphasis on character building, and emphasis on grades, free individual development, and heart-to-heart style education all have very significant influence on STEM achievement. 
Table 4

Logistic Regression Model of the Influence of Parental Participation in STEM achievement

\begin{tabular}{|c|c|c|c|c|c|c|c|c|}
\hline Variables & M1 & & M2 & & M3 & & M4 & \\
\hline PEL & $1.324 * * *$ & $(0.057)$ & $1.118 * * *$ & $(0.062)$ & $1.100 * * *$ & $(0.069)$ & $0.757 * * *$ & $(0.072)$ \\
\hline FI & 0.407 & $(0.414)$ & 0.464 & (0.432) & $0.970 *$ & $(0.470)$ & 0.860 & (0.472) \\
\hline FLS & $2.519^{*}$ & (1.026) & 1.721 & (1.056) & $2.219^{*}$ & (1.128) & $2.655^{*}$ & (1.151) \\
\hline HS & $3.226^{* * *}$ & $(0.784)$ & $2.916^{* * *}$ & $(0.815)$ & $1.978^{*}$ & $(0.901)$ & $1.852 *$ & (0.936) \\
\hline PS & & & $2.276^{* * * *}$ & $(0.209)$ & $1.610 * * *$ & $(0.231)$ & 0.305 & $(0.302)$ \\
\hline FBP & & & 1.263 & (0.899) & 1.215 & $(0.961)$ & 0.907 & (0.975) \\
\hline PSA & & & 0.172 & (0.191) & 0.103 & $(0.206)$ & 0.241 & $(0.206)$ \\
\hline PIS & & & 1.495 & (0.807) & 1.183 & $(0.871)$ & 0.931 & (0.863) \\
\hline PAST & & & $-1.038^{*}$ & (0.723) & $-1.554 * * *$ & $(0.401)$ & $-1.514 * * *$ & (0.408) \\
\hline RT & & & $-0.738^{*}$ & $(0.361)$ & -0.533 & $(0.389)$ & 0.048 & (0.397) \\
\hline MSS & & & $1.199 *$ & (0.467) & 0.864 & $(0.515)$ & 0.525 & (0.519) \\
\hline ETR & & & & & $6.086 * * *$ & $(0.900)$ & $4.085^{* * * *}$ & (0.916) \\
\hline PRE & & & & & $1.526^{*}$ & $(0.636)$ & 0.855 & (0.649) \\
\hline EAP & & & & & $-1.900^{*}$ & $(0.590)$ & -1.528 & (0.603) \\
\hline ECB & & & & & $7.009 * * *$ & $(0.801)$ & $4.003 * * *$ & $(0.853)$ \\
\hline EG & & & & & $3.049 * * *$ & $(0.818)$ & 1.401 & (0.855) \\
\hline FID & & & & & $4.355 * * *$ & $(0.931)$ & $3.001 * *$ & $(0.972)$ \\
\hline HHE & & & & & $5.520 * * *$ & $(0.854)$ & $3.107 * * *$ & (0.894) \\
\hline RPE & & & & & 2.108 & (1.144) & 1.269 & (1.190) \\
\hline SCT & & & & & $-1.556^{*}$ & $(0.969)$ & $-1.489 *$ & (0.911) \\
\hline EDO & & & & & & & $2.003 * * *$ & (0.101) \\
\hline $\mathrm{CO}$ & & & & & & & $1.754 * * *$ & $(0.405)$ \\
\hline SG & & & & & & & $9.376^{* * * *}$ & (0.416) \\
\hline SS & & & & & & & 0.645 & (0.777) \\
\hline ESI & & & & & & & 0.081 & (0.198) \\
\hline FCC & & & & & & & $2.862 * * *$ & $(0.775)$ \\
\hline SLP & & & & & & & $-1.030 * * *$ & $(0.193)$ \\
\hline Intercept & 52.611 *** & (1.263) & $58.165 * * *$ & (1.424) & $49.734 * * *$ & (1.824) & $18.545^{* * *}$ & (2.506) \\
\hline$N$ & 10491 & & 9209 & & 7668 & & 6386 & \\
\hline$R^{2}$ & 0.069 & & 0.088 & & 0.125 & & 0.253 & \\
\hline
\end{tabular}

Note. Standard errors in parentheses, $* * * \mathrm{p}<.001, * * \mathrm{p}<.01, * \mathrm{p}<.05$.

PEL: Parents education level, FI: Family income, FLS: Family living style, HS: Household structure, PS: Parents supervision, FBP: Frequent book purchase, PSA: Participating in school activities, PIS: Participating in informal studies, PAST: Participating in after-school tutoring, RT: Relationship with teachers, MSS: Making suggestions to school, ETR: Emphasis on test ranks, PRE: Pointing out reasons for errors in exams, EAP: Emphasis on academic progress, ECB: Emphasis on character building, EG: Emphasis on grades, FID: Free individual development, HHE: Heart-to-heart education, RPE: Reward-punishment education, SCT: Studying with children during tutoring, EDO: Expectations for degrees to be obtained, CO: Conflict in opinions, SG: Satisfaction with grades, SS: Satisfaction with school, ESI: Expectations for schools to improve, FCC: Frequent communication with children, SLP: Social life with peers.

Pointing out errors in exams also has a significant impact, while emphasis on academic progress has a negative influence. Overall, parents' cognitive participation explains about $12.5 \%$ of the variation in students' STEM achievement. In model 4, where parents' emotional participation is included, the influence of household structure is decreased, and the parent supervision and guidance in behavioral participation has a drastic decline in its influence, so is the cases for three cognitive participation variables: pointing out mistakes in exams, emphasis on academic progress, emphasis on grades; while the four participation in emotions variables such as expectation for degrees to be obtained by children, conflict in opinions, satisfaction with grades, and frequent communication with children have very significant impact on STEM achievement. Social life with peers has a negative influence. Overall, the model with emotional participation included can explain $25.3 \%$ of the variations in STEM achievement. 


\section{Discussion}

In this research, it is concluded that parents' emotional participation has the largest influence, explaining $25.3 \%$ of the variations, which is consistent with existing research. Similar results were obtained in the studies of Fan \& Chen (2001), who use meta-analysis and show that parental participation in school's education is able to explain more than $25 \%$ of the variations in students' test scores. In addition, some researchers (for example, Fan, 2001; Kamins \& Dweck, 1999) in their previous study have found that parental expectation has the largest moderating effect on the relationship between parental participation and students' academic achievement. However, this study makes a distinction among cognitive, behavioral, and emotional participation and their impacts on academic achievement in STEM subjects. In contrast to previous research, this paper pays attention to the characteristics of STEM subjects and the different aspects of parents' participation.

Parents' emotional participation mainly refers to their expectations of their children in education, involving children's schooling record and achievement, as well as their expectations of schools (Lee \& Bowen, 2006). Above study shows that parents' expectations have an important influence on their children's STEM academic achievement, which is confirmed by Jeynes (2005). Meanwhile, the communication between parents and children is considered an important factor in influencing the children's STEM academic achievement. Parents' satisfaction with their children's academic performance can be seen as an aspect of parental expectations, and it has a great influence on their children's STEM academic achievement. Although in China the college entrance examination is still considered the most important means for many students to change their fate, different parents have different judgment and accreditation criteria. Positive and reasonable emotional satisfaction judgments on their children's STEM academic performance will help children improve their academic performance.

In the past, the studies of the influence of family social economic status on students' STEM academic achievement took parents' highest education level achieved, family annual income, etc. as a whole, and found that they together played an important role in children's STEM academic achievement. In this study, the effects of parents' highest education level achieved, family income, family living style and family structure on children's STEM academic achievement were analyzed in detail respectively. It is found that parents' education level has a significant impact on children's STEM academic achievement in all four models; family income only affects the cognitive participation model; family living style has effect in all models except the behavioral participation model and family structure has influence on all models, and parental behavior and emotional participation can weaken the influence of family structure to a certain extent. Although single-parent families have a negative impact on their children's STEM academic achievement, single parents' behavioral and emotional participation can compensate for the negative impact. Parents' expectation, such as Emphasis on test ranks, Emphasis on character building, Free individual development and Heart-to-heart education, have a significant impact in both cognitive and emotional models.

Although parental supervision and counseling have a great influence on their children's STEM academic achievement, statistically there is no significant relationship between these methods and parents' emotional participation in improvement of their children's academic achievement. Participating in after-school tutoring all influences negatively in the three models of parental participation. In the dimension of cognitive participation 
of parents, Emphasis on test ranks is an important factor in parents' expectations, and this type of expectation has a positive and significant impact on Chinese children's academic achievement. The democratic educational methods of parents in their participation, such as high quality interactive with children and concerning children's individuality also has a positive impact on children's STEM academic achievement.

\section{Conclusion}

Family, school, and community education are the three components of the modern national education. Among the three, family education is the foundation with advantage in education time, content and techniques, and a unique method that cannot be replaced by the other two (Epstein, \& Van Voorhis, 2010). This study indicates that parental participation in school is important for building a communicating, coordinating mechanism between the two, and improving the academic achievement of students. Four nested regression models respectively for family social economic status, family structure, and participation in behaviors, participation in cognition, and participation in emotions are estimated in this study, and the results show that each of the four models has a positive influence on students' academic achievement in STEM subjects, with increasing explanatory power. As long as social inequality exists, inequality in educational opportunity won't go away with educational expansion (Breen \& Jonsson, 2005; Lucas, 2001; Pfeffer, 2008). In general, in the socioeconomic backgrounds of a family, parents' education level has the greatest impact on the academic achievement of children, and the impact of family income is relatively weak. In the three models in which parents participate in their children's school education, emotional participation has the greatest impact on children' STEM academic achievement, and can compensate for the negative effects brought about by some adverse family factors, for instance, single-parent families. Parental expectations are mainly on emotional participation, and it also involves a little cognition. The contents of these parents' expectations are particularly effective in affecting children's STEM academic achievement, and the expectation modes of parents, based on expectancy-value theory, affect children's motives and thus influence their STEM academic achievement. Democratic educational atmosphere and emotional exchanges are more prone to facilitate children's STEM academic performance. In the follow-up study, it is necessary to further explore and figure out the function mechanism of expectancy-value theory in the parental participation in children's STEM education.

\section{References}

Ames, C. (1992). Classroom: Goals, structures and student motivation. Journal of Educational Psychology, 84(3), 261-271.

Breen, R. \& Jonsson, J. O. (2005). Inequality of opportunity in comparative perspective: Recent research on educational attainment and social mobility. Annual Review of Sociology, 31, 223-243. https://dx.doi.org/10.1146/annurev.soc.31.041304.122232 
An, Wang, Yang, Du / A Study on the Effects to Students' STEM Academic Achievement with Chinese Parents....

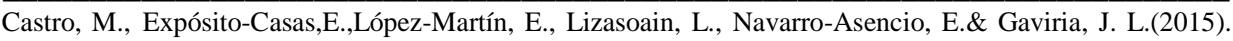
Parental involvement on student academic achievement: A meta-analysis. Educational Research Review, 14(1), 33-46. https://dx.doi.org/10.1016/j.edurev.2015.01.002

Christenson, S. L., Rounds, T. \& Gorney, D. (1992). Family factors and student achievement: An avenue to increase students' success. School Psychology Quarterly, 7(3), 178-206.

Codjoe, H. M. (2007). The Importance of home environment and parental encouragement in the academic achievement of African-Canadian Youth. Canadian Journal of Education,30(1), 137-156. https://eric.ed.gov/?id=EJ771850

Cooper, C. R., Chavira, G., \& Mena, D. D. (2005). From pipelines to partnerships: A synthesis of research on how diverse families, schools, and communities support children's pathways through school. Journal of Education for Students Placed at Risk, 10(4), 407-430. https://dx.doi.org/10.1207/s15327671espr1004_4

Epstein, J. L. (1992). School and family partnerships. In M. Aiken (Ed.), Encyclopedia of educational research (6th ed., pp. 1139-1 151). New York: Macmillan.

Epstein, J. L. (2001). School, family, and community partnerships: Preparing educators, and improving schools. Boulder, CO: Westview Press.

Epstein, J. L. \& Sanders, M. G. (2002). Family, school, and community partnerships. In Bornstein, M. H. (Ed.), Practical issues in parenting (2nd ed., pp. 407-438). Handbook of parenting Mahwah, NJ: Erlbaum.

Epstein, J. L. (1990). School and family connections: Theory, research, and implications for integrating sociologies of education and family. Marriage \& Family Review, 15(1-2), 99-126. https://dx.doi.org/10.1300/J002v15n01_06

Epstein, J., \& Van Voorhis, F. (2010). School counselors' roles in developing partnerships with families and communities for student success. Professional School Counseling, 14(1), 1-14.

Fan, X. \& Chen, M. (2001). Parental Involvement and Students' Academic Achievement: A Meta-Analysis. Educational Psychology Review, 13(1), 1-22. https://link.springer.com/article/10.1023/A:1009048817385

Feuerstein, A. (2000). School characteristics and parent involvement: Influences on participation in children's schools. The Journal of Educational Research, 94(1), 29-40. https://dx.doi.org/10.1080/00220670009598740

Flouri, E., \& Buchanan, A. (2004). Early father's and mother's involvement and child's later educational outcomes. British Journal of Educational Psychology, $74 \quad$ (2), 141-153. https://dx.doi.org/10.1348/000709904773839806

Grolnick, W. S., \& Ryan, R. M. (1989). Parent styles associated with children's academic self-regulation and competence in school. Journal of Educational Psychology, 81, 143154.

Hill, N. E., \& Tyson, D. F. (2009). Parental involvement in middle school: A meta-analytic assessment of the strategies that promote achievement. Developmental Psychology, 45(3), 740-763.

Ho, S.C.(1995). Parent Involvement: A comparison of different definitions and explanations. Education Journal, 23(1), 39-68.

Hong, S., \& Hsiu-Zu, H. (2005). Direct and indirect longitudinal effects of parental involvement on student achievement: Second-order latent growth modeling across ethnic groups. Journal of Educational Psychology, 97(1), 32-42. http://dx.doi.org/10.1037/0022-0663.97.1.32 
Harackiewicz, J. M., Rozek, C. S., Hulleman, C. S., \& Hyde, J. S. (2012). Helping parents to motivate adolescents in mathematics and science: An experimental test of a utility-value intervention. Psychological Science, 23, 899-906. http://dx.doi.org/10.1177/0956797611435530

Hokoda, A., \& Fincham, F. D. (1995). Origins of children's helpless and mastery achievement patterns in the family. Journal of Educational Psychology, 87, 375-385. http://dx.doi.org/10.1037/0022-0663.87.3.375

Jeynes, W. H. (2003). A meta-analysis: the effects of parental involvement on minority children's academic achievement. Education \& Urban Society, 35(2), 202-218. http://dx.doi.org/10.1177/0013124502239392

Jeynes, W. H. (2005). A meta-analysis of the relation of parental involvement to urban elementary school student academic achievement. Urban Education, 40(3), 237-269. http://dx.doi.org/10.1177/0042085905274540

Kamins, M. L., \& Dweck, C. S. (1999). Person versus process praise and criticism: Implications for contingent self-worth and coping. Developmental Psychology, 35, 835-847.

Kellaghan, T., Sloane, K., Alvarez, B., \& Bloom, B. S. (1993). Involving parents in home processes and learning. In The home environment and school learning: Promoting parental involvement in the education of children. San Francisco: Jossey-Bass.

Lucas, S. (2001). Effectively maintained inequality: Education Transitions, track mobility, and social background effects. The American Journal of Sociology, 106(6), 1642-1690. http://dx.doi.org/10.1086/321300

Lee, J. S., \& Bowen, N. K. (2006). Parent involvement, cultural capital, and the achievement gap among elementary school children. American Educational Research Journal, 43(2), 193-218. http://dx.doi.org/10.3102/00028312043002193

Lamborn, S., Brown, B., Mounts, N., and Steinberg, L. (1992). Putting school in perspective: The influence of family, peers, extracurricular participation, and part-time work on academic engagement. In Newmann, F. (ed.), Student Engagement and Achievement in American Secondary Schools. New York Teachers College Press, New York.

McInerney, D. M. (2008). Personal investment, culture and learning: Insights into school achievement across Anglo, Aboriginal, Asian and Lebanese students in Australia. International Journal of Psychology, 43(5), 870-879. https://dx.doi.org/10.1080/00207590701836364

Pfeffer, F. T. (2008). Persistent inequality in educational attainment and its institutional context. European Sociological Review, 24(5), 543-565. https://dx.doi.org/10.1093/esr/jcn026

Pomerantz, E. M., Moorman, E. A. \& Litwack, S. D. (2007). The how, whom, and why of parents' involvement in children's academic lives: More is not always better. Review of Educational Research, 7(3), 373-410. https://dx.doi.org/10.3102/003465430305567

Prater, D. L., Bermúdez, A. B., \& Owens, E. (1997). Examining parental involvement in rural, urban, and suburban schools. Journal of Research in Rural Education, 13(1), 72-75.

Rodriguez, A. J., Collins-Parks, T., \& Garza, J. (2013). Interpreting research on parent involvement and connecting it to the science classroom. Theory Into Practice, 52(1), 51-58. https://dx.doi.org/10.1080/07351690.2013.743775 
An, Wang, Yang, Du / A Study on the Effects to Students' STEM Academic Achievement with Chinese Parents....

Seginer, R. (2006). parental educational involvement: A developmental ecology perceptive. Parenting: Science and Practice, 6(1), 1-48. https://doi.org/10.1207/s15327922par0601_1

Schunk, D. H., Pintrich, P. R., \& Meece, J. L. (2008). Motivation in education: Theory, research and application. Upper Saddle River, NJ and Columbus, OH: Pearson.

Tan, E. T., \& Goldberg, W. A. (2009). Parental school involvement in relation to children's grades and adaptation to school. Journal of Applied Developmental Psychology, 30(4), 442-453. https://dx.doi.org/10.1016/j.appdev.2008.12.023

Toren, N. K. (2013). Multiple dimensions of parental involvement and its links to young adolescent selfevaluation and academic achievement. Psychology in the Schools, 50(6), 634-649. https://dx.doi.org/10.1002/pits.21698

Van Voorhis, F. L. (2003). Interactive homework in middle school: Effects on family involvement and science achievement. The Journal of Educational Research, 96, 323-338. https://dx.doi.org/10.1080/00220670309596616

Wang, J.Y., Jou, M., Lv, Y.Z., Huang, C. C. (2018). An investigation on teaching performances of model-based flipping classroom for physics supported by modern teaching technologies. Computers in Human Behavior, 84, 36-48. https://dx.doi.org/10.1016/j.chb.2018.02.018

Wei, W., Wu, Y.F., Lv, B., Zhou, H., Han, X.H., Liu, Z. M., \& Luo, L. (2016). The Relationship Between Parental Involvement and Elementary Students' Academic Achievement in China: One-Only Children vs. Children with Siblings. Journal of Comparative Family Studies, 47(4), 483-500.

Wentzel, K. R. (1998). Social relationships and motivation in middle school: The role of parents, teachers, and peers. Journal of Educational Psychology, 90(2), 202-209. 